\title{
KEMAMPUAN NEGOSIASI DITINJAU DARI KETRAMPILAN KOMUNIKASI DAN JENIS KELAMIN
}

\author{
RONI KAUSYAR \\ Universitas Gadjah Mada
}

INTISARI

Penelitian ini bertujuan untuk mengetahui hubungan antara ketrampilan komunikasi dan jenis kelamin dengan kemampuan negosiasi. Hiporesis penalitan ini adalah (a) ada hubungan positf antara ketrampilan komunikasi dengan kemampuan negosiasi, (b) ada perbedaan kemampuan negosiasi antara mahasiswa laki-laki dan wanita Mahasiswa laki-laki iebih tinggi kemampuan negosiasinya dibanding mahasiswa wanita

Populasi dalam penelitian ini adalah mahasiswa S1 angkatan 1998, 1999, dan 2000 Fakuitas Psikoiogi UGM yang masih aktif kuliah, dengan jumlah 395 orang. Pengambilan sampel dilakukan secara unconditioned random sampling sebanyak 100 orang dari 395 anggota populasi. Alat ukur yang digunakan dalam penelitian ini adalah Skala Kemampuan Negosiasi dan skala Ketrampilan KomunikasiBerdasarkan hasil uji Spearman's rank order correlation untuk membuktikan hipotes is pertama. dan uj U mann Whitney untuk membuhtikan hipotesis kedua, diperoleh hasil sebagai berikut: Ada korelasi positif yang signifikan antara ketrampilan komunkasl dengan kemampuan negosiasi ( $r x y=0,757$; $p=0,000$ ). Semakin tinggi ketrampilan komunikasi, maka semakin tinggi kemampuan negosiasi, dan sebaliknya semakin rendah ketrampilan komunikasi, maka semakin rendah kemampuan nogosiasi. Tidak ada perbedaan kemampuan negosiasi yang signifikan antara laki-laki dan perempuan $(U=779,0 ; Z=1,755 ; p=0,079)$.

Kata Kuncl: Kemampuan negosiasi, ketrampilan komunikasi, jenis kelamin.

RONI KA USY AR, lahir of Bandar Lampung pada 7 September 1978, dalah alumnus Fakultas Psikologi UGM. Banyak melakukan penelitian dan mendapatkan berbagai penghargaan atas berbagai penelitian yang dilakukannya.

\section{PENDAHULUAN}

Manusia dalam memenuhi kebutuhan hidupnya sangat terikat dengan orang lain dalam sualu interaksi. Interaksi yang dilakukan oleh manusia dapat dilakukan metalui hubungan antara individu dengan individu, individu dengan kelompok, atau kelompok dengan kelompok.

Konflik dapat terjadi ketika manusia berinteraksi. Hal itu disebabkan celah perbedaan kebutuhan, kesalahpahaman, atau taktor-faktor lainnya. Konflik tidak 
mungkin dibiarkan berlarut-larut terjadi. Konflik harus segera diselesaikan dan diupayakan pemecahannya. Upaya untuk menyelesaikan konflik dapat dilakukan melalui jalan negosiasi. Negosiasi merupakan proses tawar-menawar yang terjadi untuk membuat sesuatu yang dapat dilakukan antara kedua belah pihak, atau untuk menyelesaikan masalah antara dua pihak (Lewicki dkk. 1999).

Pada tataran praktik, negosiasi sering mengalami kegagalan, sehingga kesepakatan yang ingin dicapai tidak terwujud. Meskipun negosiasi terjadi setiap hari, kadang-kadang orang gagal menghasilkan persetujujan, apalagi ketika menegosiasikan konflik-konflik yang bersifat kompleks (Weingart dkk., 1996). Menurut Weingart dkk. (1996), kegagalan dalam negosiasi dișebabkan karena kurangnya pemahaman mereka terhadap kebutuhan atau tuntutannya. Hal tersebut terjadi karena mereka mengalami misunderstanding selama proses negosiasi dan tidak memiliki kemampuan negosiasi yang baik.

Kurangnya ketrampilan komunikasi negosiator selama negosiasi merupakan faktor yang menyebabkan terjadinya kegagalan negosiasi. Komunikasi merupakan syarat terjadinya hubungan interaksi sosial (Soekanto, 1990). Arti penting dari komunikasi adalah bahwa seseorang memberikan tafsiran pada perilaku orang lain (secara verbal maupun nonverbal), dan perasaanperasaan apa yang ingin disampaikan oleh orang tersebut.

Perbedaan jenis kelamin antara laki-laki dan perempuan mempunyai keterikatan juga dengan kemampuan negosiasi.

Pertanyaan penelitian yang diajukan adalah: apakah ada keterkaitan antara ketrampilan komunikasi dan jenis kelamin dengan kemampuan negosiasi?

\section{DASAR TEOAI}

Menurut Schermerhorn dkk. (1991), negosiasi adalah proses pembuatan keputusan bersama, ketika dua pihak atau lebih mempunyai perbedaan pandangan,

Feldman (1981) menggunakan istilah negosiasi yang didefinisikan sebagai social exchange, yaitu interaksi di mana individu bertukar sesuatu, penjualan barang-barang atau membagi keuntungan. Pertukaran tersebut dapal berupa hal-hal yang konkrit atau sesuatu yang abstrak, misalnya kasih sayang, cinta, dan sebagainya. Hal yang perlu diperhatikan dalam negosiasi adalah prinsip yang saling menguntungkan bagi kedua belah pihak.

Kemampuan negosiasi didefinisikan sebagai kemampuan individu untuk mengenali dan memahami aspek-aspek kemampuan negosiasi yang terdiri dari kemampuan untuk memisahkan orang dari permasalahan yang dihadapi, kemampuan untuk memfokuskan terhadap kepentingan, kemampuan untuk mengumpulkan pilihanpilihan terbaik, kemampuan untuk menggunakan kriteria-kriteria objektil sebagai titik pangkal, dan kemampuan untuk mengetahui altematif terbaik yang ingin dicapai. Aspekaspek tersebut dapat diimplementasikan dalam langkah-langkah negosiasi, diawali dengan persiapan, memulai negosiasi, proses berlangsungnya negosiasi, dan tercapainya suatu persetujuan.

Menurut Moorhead dan Griffin (1995), komunikasi adalah proses sosial untuk saling menukar informasi dan pikiran antara dua pihak atau lebih, dan dikatakan sebagai proses sosial karena melibatkan dua atau lebih pihak.

Ketrampilan komunikasi adalah kerrampilan yang dimiliki oleh seseorang dalam menyampaikan, maupun menerima pesan (simbol-simbol, tambang-lambang. atau kata-kata) kepada orang lain baik: 
secara langsung maupun tidak langsung secara efektif (Pearce dkk., 1988).

Ketrampilan komunikasi adalah suatu ketrampilan yang dimiliki oleh seseorang dalam menyampaikan maupun menerima pesan (simbol-simbol, lambang-lambang. atau kata-kata) kepada orang lain, baik secara langsung maupun tidak langsung dengan memperhatikan aspek-aspek ketrampilan komunikasi, yaitu memperhatikan secara sungguh-sungguh dan konsentrasi, mengajukan pertanyaan dengan pertanyaan terbuka, mendengarkan pasif, mendengarkan aktif, meringkas isi, dan meringkas perasaan selama proses komunikasi berlangsung.

Menurut Lewicki dkk. (1999), meskipun negosiasi sudah direncanakan, dipersiapkan, dan menggunakan strategi yang baik, tetapi komunikasi merupakan proses sentral yang menentukan tercapainya keberhasilan negosiasi. Pendapat tersebut mengisyaratkan bahwa kemampuan negosiasi negosiator untuk merencanakan, mempersiapkan, dan me nggunakan strategi negosiasi yang baik belum tentu mencapai hasil optimal, ketika negosiator tidak trampil berkomunikasi untuk mendukung kemampuan negosiasinya.

Secara teoritis terdapat perbedaan kemampuan negosiasi antara laki-laki dan perempuan. Perbedaan tersebut disebabkan karena laki-laki dan perempuan mempunyai karakteristik kepribadian yang berbeda. Menurut Williams dan Bennet (dalam Lips, 1988), perbedaan antara laki-laki dan perempuan dapat dilihat berdasarkan traits personality masing-masing. Laki-laki mempunyai sifat-sifat petualang, agresif, ambisius, asertif, -autokratik, percaya diri, logikal, rasional, maskulin, realistis, stabil, dan kuat Perempuah mempunyai sifat-sifat berperasaan, hangat, tergantung. emosional, feminin, penggoda, sensitif, dan sophisticated.
Perbedaan-perbedaan karakteristik antara laki-laki dan perempuan pada beberapa hal berimplikasi terhadap kemampuan negosiasi. Hal ini sesuai dengan pendapat Gerhart dan Rynes (1991) bahwa perbedaan jenis kelamin antara laki-laki dan perempuan berimplikasi terhadap perbedaan karakteristik kepribadian masing-masing, sehingga menjadi sumber potensial terjadinya perbedaan ke mampuan negosiasi. Karakter yang rasional, berfikir realistis, emosi yang stabil, empati, tanggungjawab, dan pengambil keputusan merupakan karakter yang mendukung keberhasilan negosiasi. Secara teoritik, karakter-karakter tersebut lebih dimiliki oleh laki-laki daripada perempuan.

\section{HIPOTES}

Hiipotesis yang diajukan dalam penelitian ini adalah:

1. Ada hubungan positif antara ketrampilan komunikasi dengan kemampuan negosiasi. Semakin tinggi ketrampilan komunikasi, maka semakin tinggi pula kemampuan negosiasi. Sebaliknya. semakin rendah ketrampilan komunikasi. maka semakin rendah pula kemampuan negosiasi.

2. Ada perbedaan kemampuan negosiasi antara laki-laki dan perempuan. Laki-laki mempunyai kemampuan negosiasi lebih tinggi daripada perempuan.

\section{METODE}

Penelitian ini terdiri dari variabel-variabel ketrampilan berkomunikasi dan jenis kelamin sebagai variabel bebas dan kemampuan negosiasi sebagai variabel tergantung.

1. Kemampuan Negosiasi merupakan kemampuan individu untuk mengenali 
danmemahamiaspek-aspekkemampuan negosiasi. Kemampuan negosiasi ini dapat diketahui dari total skor Skala Kemampuan Negosiasi yang diperoleh subjek. Semakin besar total skor Skala Kemampuan Negosiasi berarti semakin tinggi tingkat kemampuan negosiasi.

2. Ketrampilan Komunikasi merupakan ketrampilan yang dimiliki seseorang dalam menyampaikan maupun menerima pesan (simbol-simbol, lambanglambang, atau kata-kata) kepada orang lain baik secara langsung maupun tidak langsung, dengan menggunakan ketrampilan-ketrampilan komunikasi. Ketrámpitan komunikasi ini dapat diketahui dari total skor Skala Ketrampilan Komunikasi yang diperoleh subjek. Semakin besar total skor ketrampilan komunikasi berarti semakin tinggi tingkat ketrampilan komunikasi yang dimiliki.

3. Jenis kelamin adalah ciri biologis manusia yang membedakan manusia menjadi laki-laki dan perempuan. Variabel ini diungkap melalui daftar isian yang terdapat dalam setiap identitas subjek pada skala.

Populasi dalam penelitian ini adalah mahasiswa Si angkatan 1998, 1999, dan 2000 Fakultas Psikologi UGM yang masih aktif kuliah, dengan jumlah 395 orang. Pengambilan sampel dilakukan secara unconditioned random sebanyak 100 orang dari 395 anggota populasi.

Metode pengumpulan data menggunakan Skala Kemampuan Negosiasi dan Skala Ketrampilan Komunikasi. Skala Kemampuan Negosiasi ini bertujuan untuk mengetahui tingkat kemampuan negosiasi seseorang. Skala Kemampuan Negosiasi pernah diujicobakan terhadap 89 subjek mahasiswa Fakultas Psikologi UGM. Hasil uji coba menunjukkan bahwa dari 85 aitem diperoleh 58 aitem sahih dengan kisaran konsistensi internal antara 0,2776 - 0,8147, dan indeks reliabilitas a/, pha $=0,9360$. Skala Kemampuan Negosiasi terdiri dari aitem bersifat unfavorable (pernyataan berbentuk negatif), dan favorable (pernyataan berbentuk positif). Skala Kemampuan Negosiasi disusun berdasarkan aspek-aspek kemampuan negosiasi, yaitu:

a. Memisahkan orang dari permasalahan (Separate people from the problem). Negosiator harus dapat melihat problem yang sebenarnya ada dan yang menimbulkan negosiasi, bukan melihat pribadi atau diri lawan negosiasi.

b. Memfokuskan pada kepentingan, bukan pada posisi (Focus on interest not position). Posisi adalah apa yang diinginkan, sedangkan kepentingan adalah alasan menginginkan sesuatu. Mentokuskan pada Kepentingan dapat memungkinkan terjadinya persetujuan yang saling menguntungkan.

c. Menemukan pilihan yang terbaik yang mungkin didapatkan (Invent options for mutual gain). Meskipun kepentingan yang dimiliki berbeda, ada kesempatan untuk melakukan penawaran yang memungkinkan tercapainya perselujuan yang saling menguntungkan.

d. Menggunakan kriteria objektif sebagai titik tolak atau titik pangkal (Insist on objective criteria). Ada beberapa negosiasi yang tidak memungkinkan bagi timbulnya persetujuan yang saling menguntungkan. Namun adanya norma dan nilai standar dalam masyarakat diharapkan mampu untuk menciptakan situasi yang kondusil yang memungkinkan tercapainya persetujuan.

e. Mengetahui alternatif terbaik yang dapat dicapai dalam negosiasi (Know you best alternatif to negotiate agreement). Alasan bernegosiasi dengan orang lain adalah adanya kemungkinan mem- 
peroleh hasil yang lebih baik daripada ketika tidak bernegosiasi sama sekali.

Skala Ketrampilan Komunikasi bertujuan untuk mengetahui tingkat ketrampilan komunikasi seseorang. Skala Ketrampilan Komunikasi diujcobakan kepada mahasiswa Fakultas Psikologi UGM angkatan 1998,1999 , dan 2000 sebanyak 42 orang. Berdasarkan has औji coba sika la ketrampilan komunikasi, dari 61 butir aitem yang dibuat diperoleh 45 butir aitem sahih dengan sebaran konsistensi internal antara 0,32780,7379 , dan indeiks reliabilitas a/pha $=$ 0,9422 . Skala Ketrampilan Komunikasi terdiri dari aitem bersifat unfavorable (pernyataan berbentuk negatif), dan favorable (pernyataan berbentuk positif). Skala ini disusun berdasarkan aspek-aspek ketrampilan komunikasi, yaitu:

a. Memperhatikan sungguh-sungguh dan penuh konsentrasi. Ketrampilan selama proses komunikasi untuk memperhatikan sungguh-sungguh dan penuh konsentrasi apa yang diungkapkan oleh lawan bicara. Untuk menunjukkan perhatlan tersebut seseorang harus menunjukkan dalam sikap non verbal dan penyampaian pengertian secara verbal.

b. Bertanya dengan pertanyaan terbuka.Mengajukan pertanyaan-pertanyaan kepada lawan bicara dengan menggunakan bentuk pertanyaan terbuka. Pertanyaan tidak mengandung unsur jawaban "ya" atau "tidak", tetapi bagaimana lawan bicara mampu memberikan jawabanjawaban yang beisifat argumentatif.

c. Mendengarkan dengan pasif. Ketrampilan untuk secara diam dan mendengarkan sungguh-sungguh apa yang dikemukakan oleh lawan bicara tanpa interupsi, sehingga lebih memudahkan pemahaman terhadap sudut pandang lawan bicara. d. Mendengarkan dengan aktif. Ketrampilan mengungkapkan pernyataan-peryataan lawan bicara dengan menggunakan kata-kata sendiri. Ketrampilan ini menunjukkan bahwa seseorang mampu mendengarkan secara baik apa yang diungkapkan oleh lawan bicara.

e. Meringkas isi. Ketrampilan meringkas isi pesan yang dikomunikasikan secara bagian per bagian sehingga pesan tersebut dapat secara mudah diingat. Hal yang harus diperhatikan adalah ringkasan merupakan ringkasan sesaat dari bagian proses komunikasi, sedangkan rangkuman adalah keseluruhan ringkasan yang meliputi seluruh pertemuan.

f. Meringkas perasaan. Ketrampilan mengerti arti pribadi dari pesan yang dikomunikasikan oleh lawan bicara. Ketrampilan ini menuntut adanya kepekaan untuk memahami sudut pandang lawan bicara dalam mengkomunikasikan isi pesan yang disampaikan.

Metode analisis data yang digunakan untuk pengujian hipotesis pertama adalah teknik korelasi product moment. Metode analisls data untuk pengujian hipotesis kedua adalah ujitt. Sebelum dilakukan uji hipotesis dilakukan uji asumsi. Apabila uji asumsi normalitas, linieritas, dan homogenitas terpenuhi, maka uji hipotesis dapat dilakukan dengan uji statistik parametrik, tetapi apabila uji asumsi tidak terpenuhi maka uji hipotesis dilakukan dengan uji statistik non parametrik. Perhitungan uji asumsi dan uji hipotesis menggunakan paket software Statistical Program for Sosial Science (SPSS) Versi 10.1 for Windows. 


\section{HASIL PENELITIAN}

Penelitian dilaksanakan mulai tanggal 15-22 Mei 2001, bertempat di Fakultas Psikologi UGM. Peneliti menghubungi subjek penelitian satu per satu dengan dibantu oleh empat orang mahasiswa Fakultas Psikologi UGM sebagai asisten penelitian.

Pemilhan subjek dilakukan secara unconditioned random sampling. Jumlah anggota populasi dari tiga angkatan mahasiswa Fakultas Psikologi UGM (1998, 1999, dan 2000) sebanyak 395 orang. Kernudian dari jumlah tersebut diambil sampel sebanyak 100 orang secara random. Setelah dilakukan proses random, ternyata terdapat 10 orang yang merupakan subjek uịi coba skala ketrampilan komunikasi, sehingga untuk menghindari carry-over effect maka kesepuluh orang tersebut tidak diikutkan kernbali, dan jumlah sampel menjadi 90 orang. Pelaksanaan random dilakukan menggunakan prograrn randomdari software turbo pascal versi 7 for windows. Berdasarkan hasil randomdiperoleh komposisi jenis kelamin sampel penelitian, yaitu 39 orang laki-laki dan 51 orang perempuan.

Langkah berikutnya, peneliti menjelaskan cara pengisiąn skala kemarnpuan negosiasi dan skala ketrampilan kornunikasi sesuai dengan yang tertulis pada instruksi pengisian skala. Setelah peneliti mernastikan tidak ada pertanyaan, subjek dipersilakan untuk mengisi kedua skala. Setelah selesai mengisi kedua skala secara lengkap, subjek mengumpulkan kedua skala tersebut kepada asisten penelitian. Waktu pengisian kedua skala kurang lebih selarna 30 menit. Proses penelitian ditutup dengan mengucapkan terima kasih kepada subjek penelitian atas partisipasi dan kerjasamanya.

Sebelum dilakukan uji asumsi terhadap data ketrampilan komunikasi dan kemampuan negosiasi, dan uji hipotesis, peneliti melakukan pembobotan terhadap skor masing-rnasing aspek kemampuan negosiasi. Pembobotan dilakukan hanya pada skor kemarnpuan negosiasi, karena skala kernarnpuan negosiasi mempunyai distribusi aitem untuk masing-masing aspek tidak seimbang. Pembobotan dilakukan menggunakan skor standar $\mathrm{T}=10 \mathrm{z}+50$.

Uii normalitas Kolmogorov-Smirnov menunjukkan perolehan hasil distribusi yang tidak normal pada skor kemampuan negosiasi $(Z=1,494 ; p=0,023)$, dan distribusi yang tidak normal pada skor ketrampilan komunikasi ( $Z=1,790 ; p=0,003)$.

Uji linieritas Levene menunjukkan perolehan linieritas hubuingan antara skor ketrampilan komunikasi dengan kemampuan negosiasi $(F=249,586 ; p=0,000)$.

Uji hornogenitas Levene menunjukkan perolehan varians yang homogen antara skor kemampuan negosiasi kelompok lakilaki dan perempuan (nilai $=0,073 ; p=0,788$ ).

Berdasarkan hasil uji asumsi tersebut; maka langkah selanjutnya adalah melakukan uji hipotesis dengan menggunakan uji statistik non parametrik. Berdasarkan hasil uji Spearman's rank order correlation untuk membuktikan hipotesis pertama, dan uji $U$ mann Whilneyuntuk membuktikan hipotesis kedua, diperoleh hasil sebagai berikut:

a. Ada korelasi positif yang signifikan antara ketrampilan komunikasi dengan kemampuan negosiasi ( $r x y=0,757$; $p=0,000$ ). Semakin tinggi ketrampilan komunikasi, maka semakin tinggi kemampuan negosiasi, dan sebaliknya semakin rendah ketrampilan komunikasi, maka semakin rendah kemampuan negosiasi.

b. Tidak ada perbedaan kemampuan negosiasi yang signifikan antara laki-laki dan perempuan $(U=779.0 ; Z=-1,755$; $p=0079$, 


\section{PEMBAHASAN}

Adanya hubungan antara ketrampilan komunikasi dengan kemampuan negosiasi terbukti dalam penelitian ini ( $\mathrm{rxy}=0,757 ; \mathrm{p}=$ 0,000 ). Hal ini sesuai dengan pendapat beberapa ahli. Bazerman dkk. (dalam Weingart dkk., 1996) menyatakan bahwa proses komunikasi dan mengkoordinasikan permintaan antara masing-masing pihak memungkinkan untuk mencapai persetujuan secara maksimal. Weingart dkk. (1996) secara jelas menyatakan bahwa kegagalan negosiasi terjadi karena negosiator tidak menguasai ketrampilan komunikasi untuk mengkomunikasikan kebutuhan atau tuntutannya.

Pendapat para ahli tersebut telah dibuktikan dalam penelitian ini, nilai pengaruh (koefisien determinasi) ketrampilan komunikasi terhadap kemampuan negosiasi $(\mathrm{R} 2=\mathrm{rxy} 2=0,7572=0,573=57,3 \%)$ perlus ditindaklanjuti. Hal ini berarti perlu dllakukan kegiatan-kegiatan yang membantu peningkatan ketrampilan komunikași mahasiswa Fakultas Psikologi UGM, seperti pelatihan komunikasi efektif, wawancara, presentasi, dan diskusi.

Arti penting kètrampilan komunikasi dalam negosiasi adalah menciptakan kondisi saling terbuka, saling memahami sudut pandang masing-masing pihak, dan mencapai kesepakatan bersama dalam waktu yang tidak berlarut-larut.

Bentuk komunikasi yang mendukung keberhasilan negosiasi adalah komunikasi yang bersifat multi dimensional. Menurut Situmorang dan Pintauli (1989), komunikasi multi dimensional artinya setiap kali komunikasi ditakukan, maka hal ini bukan sekedar menyampaikan isi pesan, tetapi juga menentukan kadar hubungan interpersonal (relationship dimention). Hubungan interpersonal yang terjalin harus mempu menciptakan saling pengertian, memahami masing-masing sudut pandang, empati, dan hubungan kejiasama.

Ketrampilan komunikasi negosiator juga bisa dilihat dari kemampuan untuk mengatasi hambatan-hambatan komunikasi (noise). Menurut Morhead dan Griffin (1995), noise adalah segala sesuatu yang menghambatatau mengganggu proses komunikasi misalnya faktor emosi, teknis, situasi dan kondisi. Negosiatoryang mampu mengatasi hambatan-hambatan komunikasi, akan lebih fleksibel ketika menghadapi proses negosiasi (persiapan, memulai negosiasi, proses berlangsungnya negosiasi, dan menutup negosiasi) (Lewicki dkk., 1999). Komunikasi yang akurat dan jelas (clear and accurate communication) merupakan kondisi yang mendukung kualitas keberhasilan negosiasi (Lewicki, 1999).

Teknik-teknik komunikasi yang dilakukan negosiator juga mendukung terciptanya persetujuan dalam negosiasi. Teknik-teknik tersebut dapat meminimalisasi hambatanhambatan komunikasi dan distorsi selama negosiasi (Lewicki dkk., 1999). Menurut Lewicki dkk. (1999), ada tiga teknik komunikasi yang mendukung kebehasilan negosiasi yaitu the use $d$ Questions (penggunaan pertanyaan), Listening(mendengarkan), dan Role Reversal (mengutarakan kembali)

Hasil uji hipotesis kedua menunjukkan perbedaan yang tidak signifikan antara kemampuan negosiasi laki-laki dan perempuan $(U=779,0 ; Z=-1,755 ; p=0,079)$. Padamulanya hipotesis mengasumsikan bahwa lakilaki lebih tInggi kemampuan negosiasinya daripada perempuan. Secara teoritik perbedaan tersebut terjadi karena karakteristik laki-laki lebih mendukung proses negosiasi dibandingkan perempuan. Laki-laki mempunyai karakteristik mampu mengendalikan emosi, berfikir lebih rasional, lebih berorientasi pada sudut pandang orang lain, dan lebih asertif. Perempuan mempunyai karakteristik sulit mengendalikan 
emosi, berfikir lebih didominasi oleh perasaan, lebih berorientasi pada diri sendiri, dan kurang asertif. Kenyataan yang terjadi perbedaan karakteristik antara laki-laki dan perempuan tersebut tidak menjadi harga mutlak, artinya tidak semua laki-laki mempunyai 'karakteristik laki-laki" dan sebaliknya tidak semua perempuan mempunyai "karakteristik perempuan".

Pengaruh pendidikan dan perkembangan teknologi memberikan kontribusi dalam memperkecil perbedaan peran antara lakilaki dan perempuan berdasarkan jenis kelamin.

Perkembangan pendidikan lintas gender mendorbngan perkembangan emansipasi wanita akhir-akhir ini, sehingga mampu memperkecil jarak perbedaan peran gender antara laki-laki dan perempuan.

Dinamika yang terjadi pada subjek penelitian berkaitan dengan tidak adanya perbedaan kemampuan negosiasi antara laki-laki dan perempuan, juga dapat disebabkan karena faktor perkembangan emosi, pengalaman bernegosiasi, dan interaksi sosial yang dialami subjek penelitian selama perkuliahan.

\section{PENUTUP}

Berdasarkan penelitian dan hasi analisis data yang telah dilakukan, maka dapat disimpulkan bahwa: (1) Ada hubungan yang positif antara ketrampilan komunikasi dengan kemampuan negosiasi. Semakin tinggi ketrampilan komunikasi, maka sema kin tinggi kemampuan negosiasi. Sebaliknya, semakin rendah ketrampilan komunikasi semakin rendah kemampuan negosiasi. Arti penting ketrampilan komunikasi dalam negosiasi adalah menciptakan kondisi saling terbuka, saling memahami sudut pandang masing-masing pihak, dan mencapai kesepakatan bersama dalam waktu yang tidak berlarut-larut. (2) Tidak ada pertedaan kemampuan negosiasi antara lakillaki dan perempuan. Perbedaan karakteristik antara laki-laki dan perempuan tidak menjadi prediktor untuk membedakan kemampuan negosiasi berdasarkan jenis kelamin, artinya tidak semua laki-laki mempunyai karakteristik laki-laki dan sebalknya tidak semua perempuan mempunyai karakteris tik perempuan. Faktor pengalaman bernegosiasi, pendidikan, perkembangan teknologi, perkembangan emosi, dan kondisi interaksi sosial mahasiswa Fakultas Psikologi UGM merupakan faktor yang menyebabkan tidak adanya perbedaan tersebut.

Saran-saran yang diberikan oleh peneliti adalah; (1) Mahasiswa Fakultas Psikologi UGM disarankan untuk meningkatkan interaksi sosial yang komunikatif, baik selama proses perkuliahan maupun dalam kegiatan sehari-hari, sehingga mendorong meningkatkan ketrampilan komunikasi dan kemampuan negosiasi. Ketrampilan komunikasi dan kemampuan negosiasi sangat diperlukan bagi mahasiswa Fakuitas Psikologi sebagai bekal untuk menghadapi klien. Selain itu, apabila mahasiswa Fakultas Psikologi UGM menghadapi permasalahanpermasalahan yang menuntut pelaksanaan negosiasi, maka tidak perlu mempersoakkan memilih negosiator apakah laki-laki atau perempuan. (2) Bagi peneliti selanjutnya, apa bila berminat melakukan penelitian tentang kemampuan negosiasi ditinjau dari ketrampilan komunikasi dan jenis kelamin, disarankan untuk mengontrol variabel-variabel lain seperti pengalaman negosiator, motivasi, dan komitmen untuk bekerja sama. Penelitian akan lebih lengkap lagi, apabila mengambil subjek dari variasi lain misalnya karyawan, militer, atau bidang-bidang prolesi.] 


\section{DAFTAR PUSTAKA}

Feldman. F. 1981, Social Psychology. New York Mc Graw Hill.

Gerhart, B. \& Rynes, S. 1991. Deterninants and Consequences of Salary Negotiations by Male and Female MBA Graduates. Journal of Applied Psychology, vol. 76 , No2, 256-262.

Lewicki, R.J. Sauders, D.M. \& Minton, JW. 1999. Negotiation. Third edition. Boston: McGraw-Hill Companies.

Lips, H.M. 1988. Sex and Gender: An Introduction. California: Maytield Publishing Company.

Moorhead, G. \& Griffin, RW. 1995. Organizational Behavior. Managing People and
Organizations. Boston: Houston Mifflin Company.

Pearce, C.G. Figgins, R. \& Golen, S.P. 1988. Business Communication: Principles and Applications. Second ed. New York: John Willey \& Sons.

Schermerhom, J.R. Hunt, J.G. \& Osbori, R.N. 1991. Managing Organizational Behavior. Fourth edition. New York: John Willey \& Sons, Inc.

Soekanto, S. 1990. Sosiologi suatu Pengantar. Jakarta: Rajawali Press.

Weingart, L.R. Prietula, M.J. \& Hyder, E.B. 1996. Knowledgematters: The Effect of Tactical Descriptions on Negotiation Behavior and Outcome Jounal of Personaliy and Social Psychology, vol. 70 , 1205-1217. 